\title{
Treatment of textile wastewater using a novel electrocoagulation reactor design
}

\author{
Ahmed S.N. ${ }^{1,}{ }^{*}$, Raid T. Al Khateeb ${ }^{1}$ and Shreeshivadasan C. ${ }^{2}$ \\ ${ }^{1}$ Department of Architect Engineering, College of Engineering, Almuthana University, Almuthana Governorate, Iraq. \\ 2Department of Engineering, UTM Razak School of Engineering and Advanced Technology, Universiti Teknologi Malaysia, Jalan Semarak, \\ 54100, Kuala Lumpur, Malaysia
}

Received: 10/11/2017, Accepted: 17/09/2018, Available online: 26/09/2018

*to whom all correspondence should be addressed: e-mail: ahmednamesamir@yahoo.com

\begin{abstract}
This study explored the best-operating conditions for a novel electrocoagulation (EC) reactor with the rotating anode for textile wastewater treatment. The influence of operating parameters like inter-electrode distance (IED), current density (CD), temperature, $\mathrm{pH}$, operating time (RT), and rotation speed on the removal efficiency of the contaminant was studied. A comparative study was done using conventional model with static electrodes in two phases under same textile wastewater. The findings revealed that the optimal conditions for textile wastewater treatment were attained at RT $=10 \mathrm{~min}, \mathrm{CD}=4 \mathrm{~mA} / \mathrm{cm}^{2}$, rotation speed $=150 \mathrm{rpm}$, temperature $=25^{\circ} \mathrm{C}, \mathrm{IED}=1 \mathrm{~cm}$, and $\mathrm{pH}=4.57$. The removal efficiencies of colour, biological oxygen demand (BOD), turbidity, chemical oxygen demand (COD), and total suspended solid (TSS) were 98.50\%, $95.55 \%, 96 \%, 98 \%$ and $97.10 \%$ within the first $10 \mathrm{~min}$ of the reaction. The results of the experiment reveal that the newly designed reactor incorporated with cathode rings and rotated anode impellers provide a superior treatment efficiency within a short reaction time. The novel EC reactor with a rotating anode significantly enhanced textile wastewater treatment compared to the conventional model. The values of adsorption and passivation resistance validated the pollutants removal rate.
\end{abstract}

Keywords: electrocoagulation; electrode consumption; textile wastewater; rotated anode reactor.

\section{Introduction}

Electrocoagulation (EC) process involves in-situ coagulant formation with sacrificial anode dissolution. Generally, the anode is prepared using iron or aluminium (Al) (Chen, 2004). The metal ions interact to generate insoluble $\mathrm{OH}^{-}$ ions. The generated insoluble hydroxides adsorb the contaminants from the solution either by electrostatic attraction or complexation before the coagulation (Dalvand et al., 2011). Lessening of the electrodes internal resistance drop (IR-drop) is one of the most essentials towards reducing the total cost of EC operation to enhance the current performance by enhancing the state of

Table 1. Characteristics of textile wastewater turbulence. Both oxygen and hydrogen gas emerged near the cathode and anode as soon as each gas bubble nucleates. The bubbles are like insulating spherical figures, generating a film fouls oxide over the electrode surface (passivation effects). This issue increases the total electrical resistance of the cell, thereby needing a superior quantity of electrical energy to attain the optimal removal (Martinez et al., 2000). To moderate the bubble accumulation, the electrolyte flow around the electrodes must be augmented for the bubbles to be pushed out (Mollah et al., 2004).

To proffer solution to these, the current EC reactor with rotating anode was conducted to enhance the reactors overall efficiency (Martinez-Delgadillo et al., 2012). Additionally, the leading objective of the present work is to study the treatment of textile wastewater using a novel EC reactor under optimum operating conditions and to compare the performance with that of conventional EC reactor.

\section{Materials and methods}

\subsection{Wastewater characteristics}

The wastewater used in this work was collected from a major textile-based industry in Iraq (Babylon). The industry uses the Imperon Violet KB (CAS \#: 6358-46-9) for the fabric dyeing process. Tables 1 and 2 present the main characteristics of the textile wastewater and the properties of the Imperon Violet KB, respectively.

\subsection{EC rotating anode reactor}

The novel EC reactor is used in this study is illustrated in Fig.1. The reactor ( $10 \mathrm{~L}$ working volume) had a stirred tank setting of a cylindrical form (external diameter, $180 \mathrm{~mm}$; inner diameter, $174 \mathrm{~mm}$; total length, $500 \mathrm{~mm}$ ) and was constructed from Perspex. A rotating shaft (diameter, $32 \mathrm{~mm}$ ) was attached to an adjustable speed motor in order to hold the impeller structure and also to maintain the electrode rotations. The motor is DC electrical type and supplies various steady state speeds (0-1000 rpm, USA). The electrodes were composed of aluminum (AI) substance. 


\begin{tabular}{|c|c|}
\hline Parameters & Values \\
\hline Electrical conductivity $(\mu \mathrm{S} / \mathrm{cm})$ & 1455 \\
\hline Turbidity (NTU) & 396 \\
\hline Total suspension solid, TSS (mg/L) & 3270 \\
\hline Total dissolved solid, TDS (mg/L) & 1250 \\
\hline Dissolved oxygen, DO (mg/L) & 0.72 \\
\hline $\mathrm{pH}$ & 4.50 \\
\hline Chlorides, $\mathrm{Cl}^{-}$(mg/L) & 35 \\
\hline Sulfate (mg/L) & 678 \\
\hline Phosphate (mg/L) & 7.2 \\
\hline Nitrates (mg/L) & 11 \\
\hline Phenols (mg/L) & 335 \\
\hline Oil \& Grease (mg/L) & 3.2 \\
\hline $\mathrm{BOD}(\mathrm{mg} / \mathrm{L})$ & 112 \\
\hline $\mathrm{COD}(\mathrm{mg} / \mathrm{L})$ & 990 \\
\hline
\end{tabular}

Table 2. Properties of Imperon Violet KB

Color Imperon Violet KB

\begin{tabular}{ll}
\hline Chemical formula & $\mathrm{C}_{32} \mathrm{H}_{26} \mathrm{~N}_{4} \mathrm{O}_{5}$ \\
\hline Molecular weight (g/Mol) & 546.57 \\
\hline$\lambda$ max (nm)* & 533 \\
\hline${ }^{*}$ Absorbance of 0.34 at 533 &
\end{tabular}

The rotating anode consists of 10 impellers. Each impeller consists of four main rods (length, $30 \mathrm{~mm}$; diameter, 12 $\mathrm{mm}$ ), with 10 rings used as a cathode. Each ring (diameter, $172 \mathrm{~mm}$; internal diameter, $134 \mathrm{~mm}$; thickness, $12 \mathrm{~mm}$ ) was arranged sequentially at a distance of $30 \mathrm{~mm}$ apart from each other. The total active surface area was $500 \mathrm{~cm}^{2}$, and contained three equally spaced baffles in order to stop the rotation and mass fluid's tangential flow arrangements and establish the cathode rings. The recommended surface area to volume ratio is between 5 to $45 \mathrm{~m}^{2} / \mathrm{m}^{3}$ (Holt et al., 1999). In this model, the ratio was minimum $\left(5 \mathrm{~m}^{2} / \mathrm{m}^{3}\right)$, using a small area of electrode for treating large volume of wastewater. The patent novelty filing was performed with application number: PI 2015702202.

\subsection{Experimental procedure}

EC reactor performance was characterised in terms of COD, TSS and color removal. The experiment was carried initially by studying the effect of rotational speed of anode and current density. The overall efficiency of the reactor was tested using three main variables; processing time, current density and the anode's overall rotational speed. The electrolysis time (RT) was maintained in the range of 10 to 30 minutes. Three main current densities (CD); 4, 6 and 8 $\mathrm{mA} / \mathrm{cm}^{2}$ with various steady state anode rotational speeds of 75,150 and $250 \mathrm{rpm}$ were examined at an ambient temperature $\left(25\right.$ to $27^{\circ} \mathrm{C}$ ). The three current densities were chosen based on some initial investigations and the results showed that there was no significant effect to the overall removal efficiency when the current densities were increased above $8 \mathrm{~mA} / \mathrm{cm}^{2}$. In every execution, a $10 \mathrm{~L}$ sample was utilized for the operation of EC treatment, and EC batch rounds were executed at nine different times. A primary sample was extracted and subsequently. At the end of each round, the cells were cleaned with a $5 \%$ hydrochloric acid solution for a period of 10 minutes and later scrubbed with a sponge. Both the cathode and anode were attached to the negative and positive parts of $D C$ power supply (YIZHAN, 0-40V; 0-6 A, China). The main voltage was $30 \mathrm{~V}$ for each run. A voltmeter was connected in parallel with the cell to measure its voltage. The current was maintained as invariant in every round with the use of 
a variable resistance and estimated with use of an ammeter (Aswar DT830D, China). In every iteration, the samples were allowed to settle for 30 minutes and then filtered.

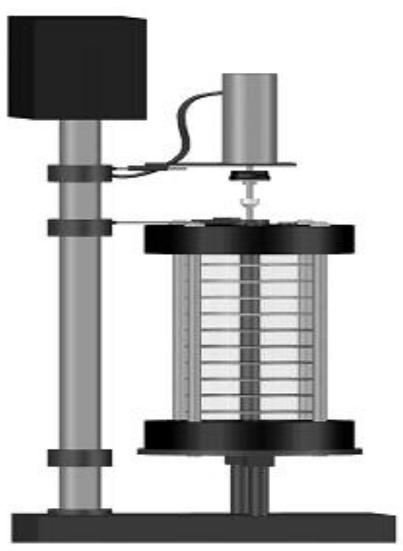

(a)

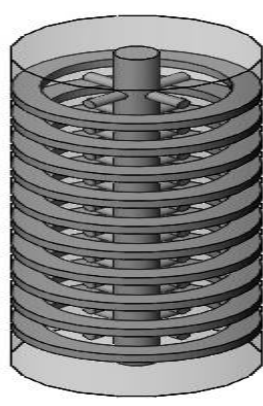

(i)

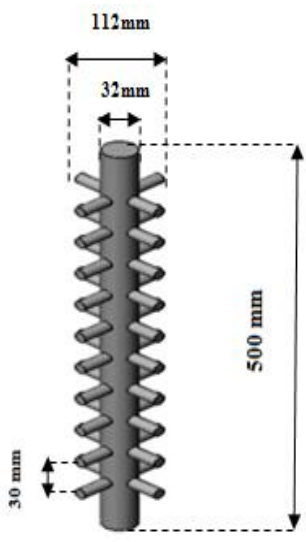

(ii)
Approximately $100 \mathrm{ml}$ of supernatant sample was gathered for analysis and investigation in replicate. Similar parameters were estimated in every replicate sample.

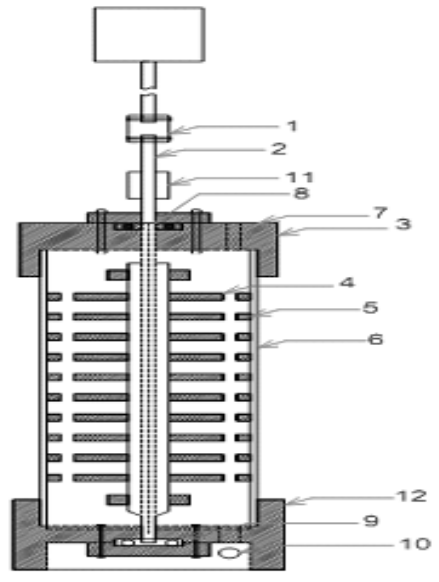

(b)

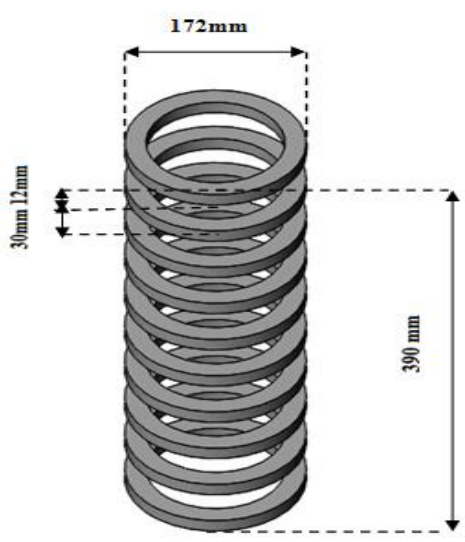

(iii)

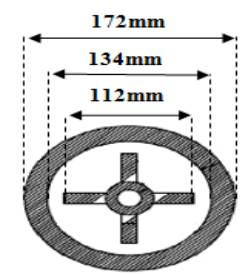

(iv)

(c)

Fig. 1 (a) Schematic diagram of EC rotated anode system. (b) Details of EC rotated anode reactor: 1. Motor varible speed ; 2. Stainless steel shaft $(D=32 \mathrm{~mm}) ; 3$. Upper teflon flange cover $(D=280 \mathrm{~mm}, H=100 \mathrm{~mm}) ; 4$. Al rods of impellers anode (no $=4$, $\mathrm{L}=30 \mathrm{~mm}, \mathrm{D}=12 \mathrm{~mm}) ; 5$. Al rings of cathode $(\mathrm{no}=10$, D.out $=172 \mathrm{~mm}$, $D . i n=132 \mathrm{~mm}, \mathrm{~T}=12 \mathrm{~mm}) ; 6$. Perspex reactor (D.out $=180 \mathrm{~mm}$,

D.in=174cm, L=500mm); 7. Upper ports (no=3, $D=10 \mathrm{~mm}) ; 8$. Ball bearing; 9 . Thrust bearing; 10. Lower port $(D=10 \mathrm{~mm}) ; 11$.

Zoom couping; 12. Lower teflon flange cover $(D=280 \mathrm{~mm}, \mathrm{H}=100 \mathrm{~mm})$. (c) Configurations of electrodes: i. Anode and cathode; ii. Impellers of anode; iii. Rings of cathode; iv. Top view of impellers anode and rings cathode.

The experiment was carried out at four different operational parameters to obtain greater optimal conditions. The effect of $\mathrm{pH}$ on the EC process was carried out at different $\mathrm{pH}$ values. The $\mathrm{pH}$ was gradually increased from 5 to 10 by adding $0.5 \mathrm{M} \mathrm{NaOH}$ during the experiment. A particular number of supporting electrolytes such as $\mathrm{NaCl}$ and $\mathrm{Na}_{2} \mathrm{SO}_{4}\left(0.0,0.02,0.05\right.$, and $\left.0.10 \mathrm{~kg} / \mathrm{m}^{3}\right)$ were introduced into the wastewater to investigate the impact electrolysis support on the removal performance. The effect of temperature was carried out in the range of $25-$ $45^{\circ} \mathrm{C}$ using water circulation (WiseCircu Model WCR-P6) to maintain the temperature during EC process. Inter electrode distance between the impellers of the anode and rings of the cathode were achieved for distances between
$1,1.5$ and $2 \mathrm{~cm}$. Towards the completion of the experiment, the optimum operational condition was carried out again in triplicate to validate the EC process's accuracy and reproducibility for treating the textile wastewater contaminants. For comparison study using same textile wastewater, the results of the conventional model with parallel electrodes in two phases have been observed by our previous researches using EC alone by aluminium plates (Naje, Chelliapan, Zakaria, \& Abbas, 2015b) and on enhancing of EC process by combining with electrooxidation (EO) using titanium plates (Naje et al., 2015a).

The passivation and adsorption phenomenon were also investigated using the electrochemical impedance spectroscopy. The experiments were performed with the 
potential amplitude of the $A C$ signal kept at $10 \mathrm{mV}$, and the measured frequency range was $0.01-10^{5} \mathrm{~Hz}$. An EC-Lab SP300 potentiostat with EC-Lab software V10.12 was used to perform the electrochemical impedance assays. Impedance runs were carried out in a single-compartment, three-electrode system, which consisted of an aluminium electrode (1:25 of the original size) as the working electrode, $\mathrm{Ag} / \mathrm{AgCl}(3 \mathrm{M} \mathrm{KCl})$ electrode as a reference electrode, and a platinum wire as counter electrode.

\subsection{Chemical analysis}

The overall treatment performance of the novel electrolysis was analyzed in terms of COD, TSS and color removal performances. The electrical potential was maintained at 30 volts for each iteration. The COD was estimated by a Closed Reflex-Titrimetric method. The TSS and TDS were measured by Gravimetric method. Phenol was examined by high-performance liquid chromatography (HPLC), Agilent Technology 1200 series. ODS hypersil C18 column ( $4.6 \mathrm{~mm} * 150 \mathrm{~mm} * 5 \mu \mathrm{m}$ ) at 25 was used as the separation column for phenol and aromatic compounds using acetonitrile/water (60/40, v/v) as the mobile phase. The injection volumes and the mobile phase flow rate were $5 \mu \mathrm{L}$ and $1 \mathrm{~mL} / \mathrm{min}$ respectively. The detection wavelength was set at $254 \mathrm{~nm}$. The samples were filtered through a $0.25 \mu \mathrm{m}$ membrane filter. The oil and grease (O\&G) was estimated by Solvent Extraction method. The BOD and DO (dissolved oxygen) were measured by DO meter (Eutech Instrument Cyberscan 110). The pH (model pHM84), conductivity (HANNA HI-99301), and turbidity (HACH 2100P) were also investigated in this study. The color was determined via absorbance with a UV-Vis Spectrophotometer (Shimadzu UV 1700) with a wavelength that corresponds to the peak absorbance value for textile wastewater $(533 \mathrm{~nm})$. The samples were filtered using Whatman $934 \mathrm{AH}$ filter. The rotational speed of the rotated anode was maintained by a microprocessor digital meter. Ion analysis was performed using ionic chromatography ICS-2000. All the analytical work was conducted according to the procedures prescribed in the standard methods (APHA, 1998). The computation of TSS, COD and color removal was carried out using formulas specified by among others (Aoudj et. al., 2010; Bayar et al., 2011; Merzouk et al., 2010; Un and Aytac, 2013).

\subsection{Sludge compaction analysis}

The textile wastewater sludge was allowed to sit for $1 \mathrm{~h}$ to increase the consolidation of the sediments. The two

Total operating cost $=a \mathrm{C}_{\text {energy }}+b \mathrm{C}_{\text {electrode }}+d \mathrm{C}_{\text {sludge }}+e \mathrm{C}_{\text {chemicals }}$

$$
\begin{aligned}
& C_{\text {energy }}=\mathrm{UIRT} / \mathrm{V} \\
& \text { Celectrode }=\mathrm{M}_{\mathrm{w}} \mathrm{IRT} / \mathrm{z} \mathrm{FV}
\end{aligned}
$$

Where $\mathrm{C}_{\text {energy, }} \mathrm{C}_{\text {electrode, }} \mathrm{C}_{\text {sludge }}, \mathrm{C}_{\text {chemicals }}, a, b, d, e, \mathrm{U}, \mathrm{I}, \mathrm{RT}, \mathrm{V}$, $M_{w}, z$, and $F$ denote energy intake for every cubic meter of wastewater $\left(\mathrm{kWh} / \mathrm{m}^{3}\right)$, electrode intake for treating $1 \mathrm{~m}^{3}$ of wastewater $\left(\mathrm{kg} / \mathrm{m}^{3}\right)$, amount of sludge for every $1 \mathrm{~m}^{3}$ of wastewater $\left(\mathrm{kg} / \mathrm{m}^{3}\right)$, quantity of chemicals $\left(\mathrm{kg} / \mathrm{m}^{3}\right)$, total concentrations of cationic polymer (LPM 3135 polymer, 10 and $40 \mathrm{mg} / \mathrm{L}$ ) were examined to enhance the settling process. The volume of space taken by the solid $(\mathrm{mL})$ was checked at regular time intervals. The weight of the solid portion (the wet residue) was estimated and dried for approximately $24 \mathrm{~h}$ at $100^{\circ} \mathrm{C}$ to determine the total residual solids. The specific resistance to filtration (SRF) and the cake-dry solid were estimated to properly characterize the dewater capability of the sludge using Buchner funnel of filtration with pressure (0.015 mpas). The SRF formula (in $\mathrm{m} / \mathrm{kg}$ ) is defined as (Djedidi et al., 2009):

$$
\operatorname{RF}(\mathrm{SRF})=\left(2 \mathrm{KbPA}^{2}\right) / \mu \mathrm{aw}_{\mathrm{w}}
$$

Where $\mathrm{Kb}$ is the slope of the $V$ vs $\mathrm{t} / V$ plot, $\mathrm{A}$ is the filtered area, $P$ is the pressure during sludge filtration (mpas), $\mu$ is the viscosity of the filtrate $\left(\mathrm{N} . \mathrm{s} / \mathrm{m}^{2}\right)$, and $\mathrm{a}_{\mathrm{w}}$ is the weight of the solid per unit volume of filtrate $\left(\mathrm{kg} / \mathrm{m}^{3}\right)$. Whatman glass fiber filters (Grade 934-AH) was used. Measuring and estimating dryness of the general cake was performed using the following equation:

$$
\text { Sludge dryness }(\%)=100 \times\left[\left(m_{3}-m_{1}\right) /\left(m_{2}-m_{1}\right)\right]
$$

Where $m_{2}$ and $m_{1}$ are the mass of the cup (with the membrane) before and after the filtration process, respectively, and $m_{3}$ is the mass of the same cup after the drying process at $100^{\circ} \mathrm{C}$ for $24 \mathrm{~h}$.

A sludge volume index (SVI) was implemented to decide the settling properties of the sludge suspensions. The SVI $(\mathrm{mL} / \mathrm{g}$ ) is the volume (in $\mathrm{mm}$ ) used by $1 \mathrm{~g}$ of a suspension subject to $30 \mathrm{~min}$ of settling (APHA, 1998). The SVI is defined as:

$$
\mathrm{SVI}=\mathrm{VD}_{30} / \mathrm{TSS}
$$

Where $V D_{30}$ is the volume of settled sludge after $30 \mathrm{~min}$ $(\mathrm{mL} / \mathrm{L})$ and TSS is the concentration of suspension solids (g/L).

\subsection{Economic analysis}

The total operation costs for wastewater treatment process comprises of electricity, sludge disposal, chemical usage, maintenance, labour, and equipment. In the EC process, the main operating costs are of the electrode material and electricity. In this work, the cost of sludge disposal and chemical supplements were also included. Total operating costs were calculated based on the following equations (Dalvand et al., 2011):

electricity costs (approximately $0.075 \mathrm{US} \$ / \mathrm{kWh}$ ), cost of aluminum or iron $(2.5 \mathrm{US} \$ / \mathrm{kg})$, cost of sludge disposal including transportation and excluding the drying $(0.06 \mathrm{US} \$ \mathrm{~kg})$, cost of chemicals which can be added $(\mathrm{NaCl}$

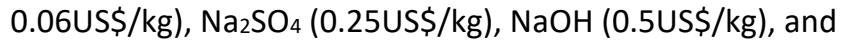


LPM 3135 polymer (3.0US\$/kg), voltage, current intensity, EC electrolysis time, working volume of textile wastewater, molecular weight of the aluminum $(26.98 \mathrm{~g} / \mathrm{mol})$ or iron $(55.84 \mathrm{~g} / \mathrm{mol})$, amount of electrons moved (3), and Faraday constant $(96500 \mathrm{C} / \mathrm{mol})$, respectively. The operating expense was computed based on the prices acquired from the Iraqi market in the year 2017. For EC rotating anode, the overall electrical energy consumption was computed based on the following equation:

$$
C_{\text {energy }}\left(\mathrm{kWh} / \mathrm{m}^{3}\right)=\left(C_{\text {energy }}\right) \mathrm{s}+\left(C_{\text {energy }}\right) \mathrm{M}
$$

Where ( $C_{\text {energy }}$ s represents the value of the electrical energy consumption of the reactor (electricity input to the anode and the cathode due to DC power supply), and (Cenergy) $\mathrm{M}$ represents electrical energy consumption rate of the DC motor anode rotation. Both the $\left(C_{\text {energy }}\right) s$ and (Cenergy) M was computed from Eq. (5).

\section{Results and discussion}

\subsection{Efficiency and reproducibility of the EC process performance}

The investigations of the best parameters have been discussed in our previous research (Naje, Chelliapan, Zakaria, \& Abbas, 2016). The main EC operation of the textile wastewater was performed three different times to validate the performance of the application using the optimal conditions $\left(C D=4 \mathrm{~mA} / \mathrm{cm}^{2}, \mathrm{RT}=10\right.$ minutes, rotational speed $=150 \mathrm{rpm}, \mathrm{pH}=4.57$, temperature $=25^{\circ} \mathrm{C}$, and $\left.d_{e}=1 \mathrm{~cm}\right)$. The performance of the $E C$ reactor was evaluated in terms of the levels of COD, TSS, color, turbidity, BOD, O \& G, TDS, DO, phenols, sulfate, phosphate, nitrates and aluminum. An overall summary of the parameter results is presented in Fig. 2 and Table 3. The EC operation generates an overall COD removal efficiency of $97.1 \%$. After the treatment operation, the $\mathrm{BOD}_{5}$ and $\mathrm{O} \& \mathrm{G}$ within the effluent had values of 5 and $0.1 \mathrm{mg} / \mathrm{L}$, respectively. The $O$ \& G's hydrophobic capacity leads to a superior affinity in combination with the $\mathrm{H}_{2}$ bubbles created at the cathode. The $(\mathrm{O} \& \mathrm{G})-\mathrm{H}_{2}$ complex gathers on the liquid's surface, which can be skimmed with ease (Asselin et al., 2008).

The proposed design cell of the EC allows for greater efficiencies and, at the same time, reduced energy consumption, when compared to other studies. Un and Aytac, (2013) investigated the treatment of textile wastewater using EC in a packed-bed electro-chemical reactor. The COD removal efficiency was $96.88 \%$ and the color was almost entirely removed when the EC operated for 1 hour. In contrast, in the current study, the COD removal efficiency was $97 \%$ at a reaction time of 10 minutes. Merzouk et al., (2010) also investigated the treatment of textile wastewater using EC and electroflotation in a batch reactor (density $=11.55 \mathrm{~mA} / \mathrm{cm}^{2}, \mathrm{pH}=$ 7.6, conductivity $=2.1 \mu \mathrm{S} / \mathrm{cm}$ and electrode gap $=1 \mathrm{~cm}$ ). With optimal operating conditions, the following results were achieved: TSS, 85.5\%; turbidity, 76.2\%; BOD5, 88.9\%; COD, 79.7\%; and color, 93\%. When compared with the above study, the present investigation, which uses EC alone under optimal conditions, revealed great removal efficiencies: TSS, 98\%; turbidity, 96\%; COD, 97\%; BOD5,
95.55\%; and color, over 98\%. Recently, El-Ashtoukhy et al., (2013) investigated the removal of phenol from oil refinery wastewater using an electrochemical reactor with a fixedbed anode composed of arbitrarily oriented aluminum raschig rings. At a current density of $8.59 \mathrm{~mA} / \mathrm{cm}^{2}$, a $\mathrm{pH}$ of 7 , and a $\mathrm{NaCl}$ concentration of $1 \mathrm{~g} / \mathrm{L}$, up to $80 \%$ phenol reduction was recorded in 2 hours in which the primary phenol concentration was $40 \mathrm{mg} / \mathrm{L}$.

In the current investigation, the primary phenol concentration was $350 \mathrm{mg} / \mathrm{L}$ and up to $99.99 \%$ was removed within 10 minutes, leaving $0.009 \mathrm{mg} / \mathrm{L}$ of phenol in the treated wastewater. Moreover, Delgadillo et al. (2013) studied the reduction of $\mathrm{Cr}$ (VI) to $\mathrm{Cr}$ (III) by using ferrous ions [Fe (II)] in a rotating ring iron electrode. They reported a removal of $99.9 \%$ of $\mathrm{Cr}(\mathrm{VI})$ at a reaction time in the range of 22 to 42 minutes when the angular velocity was in the range of 0 to $230 \mathrm{rpm}$ (at $5 \mathrm{~A}$ ). In the present investigation, the optimal current and the reaction time were $2 \mathrm{~A}$ and 10 minutes, confirming reduced power consumption and low operational costs. In addition, this study also demonstrated high removal of TDS (93.6\%) under optimal operating conditions, and the concentration of phosphate was reduced from 7.2 to $0.23 \mathrm{mg} / \mathrm{L}$.

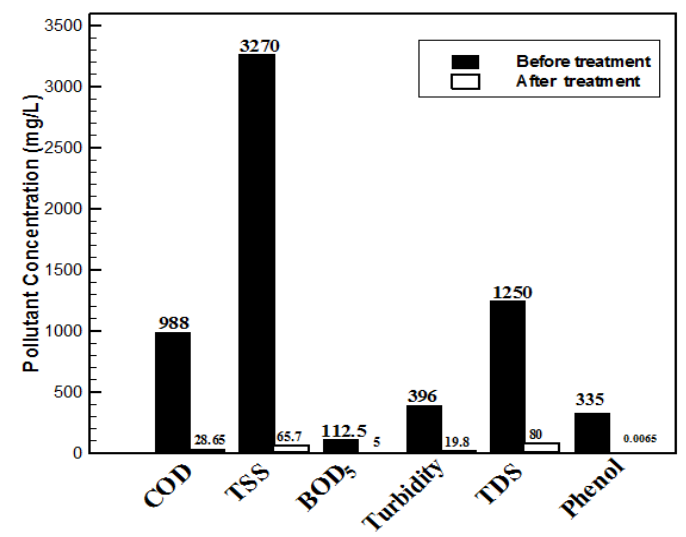

Figure 2. The removal efficiency of various variables of the textile wastewater under optimal condition

During the operation, the aluminum electrode dissolution exhibited an increase in the entire dissolved concentration from 1.5 to $6.00 \mathrm{mg} / \mathrm{L}$. Compared with the global textile wastewater quality standards (EPA, 1996), the results enable the analysis of the effectiveness of the EC operation for treating the existing textile wastewater to be used for different purposes. The results revealed that the BOD, DO, TDS, turbidity and COD are all below the standard limits. However, the overall $\mathrm{pH}$ level of the treated wastewater was somewhat basic $(6.9 \pm 0.04)$ and is under the set limits. In a similar fashion, the grease and oil as well as the total phenols were all under the allowable limits. Using the optimal conditions, the actual consumption of electrodes was $0.038 \mathrm{~kg} / \mathrm{m}^{3}$, energy consumption was $0.966 \mathrm{kWh} / \mathrm{m}^{3}$ where $0.9 \mathrm{kWh} / \mathrm{m}^{3}$ for DC power supply consumption and $0.066 \mathrm{kWh} / \mathrm{m}^{3}$ for DC motor of rotating anode. For settling metallic sludge study after adding $0.01 \mathrm{~kg} / \mathrm{m}^{3}$ LPM3135 polymers, a $5 \%$ sludge dryness and $63 \mathrm{~mL} / \mathrm{g}$ SVI was observed during the analysis. The sludge production was 
$1.44 \mathrm{~kg} / \mathrm{m}^{3}$. Furthermore, the SRF utilized in these investigations was $\left(4.6 * 10^{12} \mathrm{~m} / \mathrm{kg}\right)$. The results showed that the main operating costs for treating one cubic meter [Eq. (4)] of wastewater at the optimum operating conditions was about 0.283 US\$.

\subsection{Comparison performance of the EC rotating anode with conventional model}

Table 4 shows a comparative study between EC rotating anode and the conventional static electrodes in two phase EC process alone and EC-EO process depending on the results of each model at the optimal conditions. Each model has same optimal applied current to volume ratio $(0.2 \mathrm{~A} / \mathrm{L})$. Although the $\mathrm{EC}$ model with rotating anode have the lowest surface area to volume ratio $\left(5 \mathrm{~m}^{2} / \mathrm{m}^{3}\right)$, it can be seen that the best removal efficiency of contaminants textile wastewater (COD, TSS, and the color) was obtained by this reactor model. The minimum reaction time (10 minutes) was achieved by EC model with rotating anode compared with conventional model in two phases $(90$ minutes) which demonstrated the activity of electrodes for the treatment and reduced significantly the energy consumption to $0.966 \mathrm{kwh} / \mathrm{m}^{3}$. Also the rotational speed of anode effects on the energy consumption by reducing the main voltage and passivation films. The EC process with rotating anode showed excellent treatment without setting the initial $\mathrm{pH}$ or using electrolysis support. The electrode consumption and sludge production was lower than the conventional model with static electrodes. As for the operating costs, the EC model with rotating anode was lower than the conventional model with static electrodes (EC rotating anode $=0.283 \mathrm{US} \$ / \mathrm{m}^{3}$, while conventional static electrode including $\quad \mathrm{EC}=1.76 \quad \mathrm{US} \$ \mathrm{~m}^{3} \quad$ and $\mathrm{EC}-\mathrm{EO}=1.69 \mathrm{US} \$ \mathrm{~m}^{3}$ ).

Table 3. Effectiveness and reproducibility of the performance of $\mathrm{EC}$ rotated anode in treating textile wastewater at optimal conditions $\left(C D=4 \mathrm{~mA} / \mathrm{cm}^{2}, \mathrm{RT}=10 \mathrm{~min}\right.$, rotational speed $=150 \mathrm{rpm}, \mathrm{pH}=4.57$, Temperature $\left.=25^{\circ} \mathrm{C}, \mathrm{d}_{\mathrm{e}}=1 \mathrm{~cm}\right)$

\begin{tabular}{|c|c|c|c|c|}
\hline Parameters & $\begin{array}{c}\text { Raw } \\
\text { effluent }\end{array}$ & Treated effluent & $\begin{array}{l}\text { Allowable Limit (EPA) } \\
1996\end{array}$ & Removal (\%) \\
\hline Electrical conductivity $(\mu \mathrm{S} / \mathrm{cm})$ & 1455 & 2000 & ID & \\
\hline Initial pH & 4.57 & 4.57 & - & \\
\hline Final $\mathrm{pH}$ & $\overline{\bar{\nu}}$ & 6.92 & $6-8$ & \\
\hline Energy consumption $\left(\mathrm{kwh} / \mathrm{m}^{3}\right)$ & - & 0.966 & - & - \\
\hline Electrode consumption $\left(\mathrm{kg} / \mathrm{m}^{3}\right)$ & - & 0.038 & & - \\
\hline Sludge production $\left(\mathrm{kg} / \mathrm{m}^{3}\right)$ & & 1.44 & & \\
\hline Polymer consumption $\left(\mathrm{kg} / \mathrm{m}^{3}\right)$ & & 0.01 & & \\
\hline O\&G (mg/L) & 3 & 0.1 & $5-40$ & 96.66 \\
\hline $\mathrm{BOD}_{5}(\mathrm{mg} / \mathrm{L})$ & 112.5 & 5.00 & $5-45.5$ & 95.55 \\
\hline $\mathrm{COD}(\mathrm{mg} / \mathrm{L})$ & 988 & 28.65 & $20-500$ & 97.10 \\
\hline TSS (mg/L) & 3270 & 65.70 & $60-300$ & 98.00 \\
\hline Color observance at 533 NM & 0.3400 & 0.0051 & ID & 98.50 \\
\hline TDS (mg/L) & 1250 & 80.00 & $5-180$ & 93.60 \\
\hline Turbidity (NTU) & 396 & 19.80 & $15-50$ & 96.00 \\
\hline $\mathrm{DO}(\mathrm{mg} / \mathrm{L})$ & 0.7 & 14.5 & $4.5-15$ & \\
\hline Sulfate (mg/L) & 678 & 17.00 & ID & 97.50 \\
\hline Phosphate (mg/L) & 7.2 & 0.23 & ID & 96.80 \\
\hline Nitrates (mg/L) & 11 & 0.2 & ID & 98.18 \\
\hline Phenols (mg/L) & 335 & 0.0065 & 10 & 99.99 \\
\hline Chlorides $\mathrm{Cl}^{-}(\mathrm{mg} / \mathrm{L})$ & 33 & 0.4 & ID & - \\
\hline Aluminum (mg/L) & 1.50 & 6.00 & - & - \\
\hline Electrical energy cost (US\$/m³) & - & 0.072 & - & - \\
\hline Electrode consumption cost (US\$/m³) & & 0.095 & - & $=$ \\
\hline Sludge disposition cost (US\$/m³) & & 0.086 & - & - \\
\hline Polymer cost (US\$/m³) & & 0.030 & $=$ & - \\
\hline Total operating cost (US\$/m³) & - & 0.283 & - & - \\
\hline
\end{tabular}

\subsection{Passivation and adsorption phenomenon}

Electrochemical impedance spectroscopy is one of the most efficient techniques used to investigate the electrochemical parameters of the electrode/electrolyte interface (Brett, Brett, \& Electrochemistry, 1993; Oliveira \& Oliveira-Brett, 2010). The impedance technique was used to investigate the effect of the electrode's rotational speed (rpm) on electrode passivity and color adsorption on the aluminium anode. The electrolyte was real textile wastewater and the potential of $0 \mathrm{~V}$ vs. $\mathrm{Ag} / \mathrm{AgCl}$, as well as a frequency range of $0.01-10^{5} \mathrm{~Hz}$ were used to evaluate the performance of the anode/electrolyte interface. Fig. 3 (a) shows the Nyquist plot for the anode at different rotational speeds $(0,75,100$, and $150 \mathrm{rpm})$. Two semicircles were observed at high frequencies and low frequencies. The best fits for the aluminium electrode impedance spectra are shown in Fig. 3 (b). 
Table 4. Comparison of the EC rotating anode with conventional model static electrode (EC alone and EC-EO) at optimal conditions

\begin{tabular}{lccc}
\hline Parameters & ECrotating anode & EC static electrode & EC-EO static electrode \\
\hline Materials & Al-Al & Mp Al-Bp Al & Mp Ti-Bp Al \\
\hline COD removal (\%) & 97.10 & 92.60 & 93.50 \\
\hline TSS removal (\%) & 98.00 & 96.40 & 97.00 \\
\hline Color removal (\%) & 98.50 & 96.50 & 97.50 \\
\hline Initial pH & Natural & 6.00 & 6.00 \\
\hline Conductivity $(\mu S / \mathrm{cm})$ & 2000 & 1980 & 1910 \\
\hline Current/volume ratio $(\mathrm{A} / \mathrm{L})$ & 0.2 & 0.2 & 0.2 \\
\hline Surface area/volume ratio $\left(\mathrm{m}^{2} / \mathrm{m}^{3}\right)$ & 5 & 12 & 12 \\
\hline RT $(\mathrm{min})$ & 10 & 90 & 90 \\
\hline Electrode consumption $\left(\mathrm{kg} / \mathrm{m}^{3}\right)$ & 0.038 & 0.1 & 0.087 \\
\hline Energy consumption $\left(\mathrm{kwh} / \mathrm{m}^{3}\right)$ & 0.966 & 8.49 & 9.00 \\
\hline Sludge $\mathrm{production}\left(\mathrm{kg} / \mathrm{m}^{3}\right)$ & 1.44 & 3.50 & 2.88 \\
\hline $\mathrm{NaOH}\left(\mathrm{kg} / \mathrm{m}^{3}\right)$ & No add & 1.26 & 1.20 \\
\hline $\mathrm{NaCl}\left(\mathrm{kg} / \mathrm{m}^{3}\right)$ & No add & 0.1 & No add \\
\hline Operational cost $\left(\mathrm{US} \$ / \mathrm{m}^{3}\right)$ & 0.283 & 1.76 & 1.69 \\
\hline
\end{tabular}

The fitting parameters consisted of the solution resistance $\left(R_{s}\right)$, which was in parallel with a combination of the impedance of the faradic reaction and double layer capacitance $\left(C_{d l}\right)$. Other than that, the faradic reaction impedance consisted of passivation resistance $\left(R_{c t}\right)$, together with adsorption resistance $\left(R_{a d s}\right)$ and adsorption capacitance ( $C_{\text {ads }}$ ) (Bo et al., 2012; Hernando et al., 2009; Sakharova et al., 1992). Table 5 summarizes the impedance parameters. Meanwhile, the diameter of the first semicircle represents the values of $R_{c t}$ and the second semicircle diameter represents the values of $R_{a d s}$. It is obvious from Fig.3 (a) and Table 5 that the values of $R_{c t}$ and

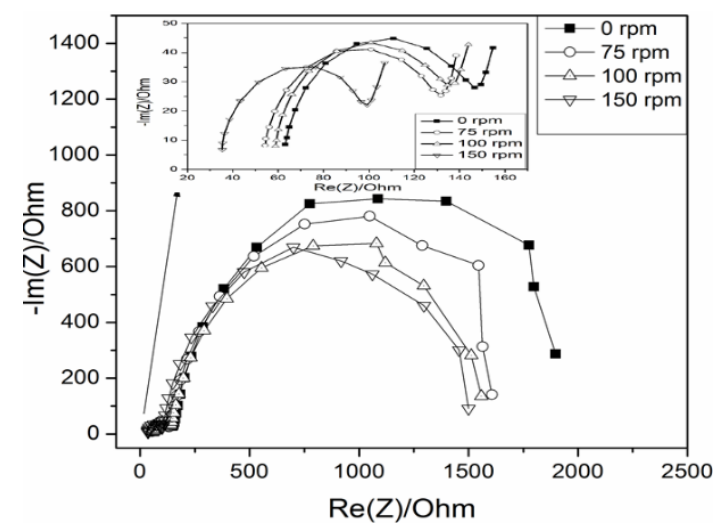

(a)
Rads decreased significantly with the increase in the rotation speed of the aluminium anode from 0 reaching a minimum at $150 \mathrm{rpm}$. This revealed that the anode-fouling rate became less, and the color adsorption rate to the anode interface became higher at $150 \mathrm{rpm}$. On the other hand, the maximum values of the double layer capacitance and adsorption capacitance occurred at $150 \mathrm{rpm}$. So, this explains the high removal rate when the anode is rotated at $150 \mathrm{rpm}$ during the EC process and validates that the model design can solve the problem statement of the previous model.

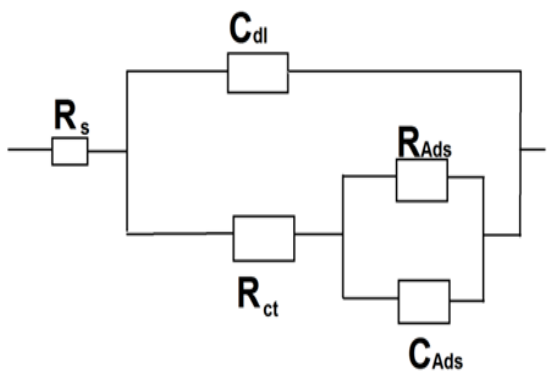

(b)

Fig. 3 (a). Nyquist plots of the aluminium anode in an aqueous solution of textile wastewater at different electrode rotation speed and $25^{\circ} \mathrm{C}$ temperature; (b). Equivalent circuits used in the fitting of the Nyquist plots.

Table 5: Electrochemical impedance data extracted from the Nyquist plots at different rotational speed (rpm)

\begin{tabular}{|c|c|c|c|c|c|}
\hline RPM & $\mathrm{R}_{s}(\Omega)$ & $R_{c t}(\Omega)$ & $\mathrm{C}_{\mathrm{dl}}(\mu \mathrm{F})$ & Rads $(\Omega)$ & $C_{\text {ads }}(\mu \mathrm{F})$ \\
\hline 0 & 63.30 & 96.98 & 0.128 & 1774 & 7.18 \\
\hline 75 & 56.90 & 88.89 & 0.129 & 1531 & 7.36 \\
\hline 100 & 59.08 & 90.00 & 0.145 & 1369 & 7.13 \\
\hline 150 & 40.54 & 41.65 & 0.412 & 1151 & 8.31 \\
\hline
\end{tabular}




\section{Conclusions}

The use of novel EC reactor in textile wastewater treatment exhibits a higher removal efficiency in comparison to the erstwhile models. The efficiency of the textile effluence pollutants removal with high values was achieved using a lower $C D$, precisely $4 \mathrm{~mA} / \mathrm{cm}^{2}$, at initial reaction period (10 $\mathrm{min}$ ) at $1 \mathrm{~cm}$ inter-electrode distance (IED) and $150 \mathrm{rpm}$ anode rotation speed. A rise in the value of $C D$ enhanced the efficiency of EC process in the treatment of textile wastewater. The setting of the solution $\mathrm{pH}$ to increase the solution temperature and the addition of any chemicals $\left(\mathrm{Na}_{2} \mathrm{SO}_{4}\right.$ or $\left.\mathrm{NaCl}\right)$ are not required. The economic viability of the operation of the reactor is influenced by the parameters. The energy and electrode consumption of the EC increases as the CD increases. The optimal energy and electrodes consumptions were $0.038 \mathrm{~kg} / \mathrm{m}^{3}$ and 0.966 $\mathrm{kWh} / \mathrm{m}^{3}$, which led to the lower cost of operation $\left(0.283 \mathrm{US} \$ / \mathrm{m}^{3}\right)$. The novel EC reactor with rotating anode significantly enhanced the textile wastewater treatment by improving the pollutants removal rate, reducing reaction time of treatment, without any additional chemicals during the process, and reducing the operation cost compared to conventional model (EC, and EC-EO). It was found that the passivation phenomenon reduced with the increased rotation speed of anode, which enhanced the EC process performance and validated the novel reactor design.

\section{Acknowledgements}

The authors thank Babylon Textile Plant, Iraq for supplying the textile wastewater. They also thank for Almuthana University Iraq and Ministry of Higher Education Iraq for funding this research.

\section{References}

Aoudj S, Khelifa A, Drouiche N, Hecini M. and Hamitouche H. (2010), Electrocoagulation process applied to wastewater containing dyes from textile industry, Chemical Engineering and Processing: Process Intensification, 49(11), 1176-1182.

APHA, AWWA. (1998). WEF (American Public Health Association, American Water Works Association, and Water Environment Federation). 1998. Standard methods for the examination of water and wastewater, 20.

Asselin M., Drogui P., Brar S.K., Benmoussa H. and Blais J-F. (2008), Organics removal in oily bilgewater by electrocoagulation process, Journal of Hazardous Materials, 151(2), 446-455.

Bayar S., Yıldız Y.Ş., Yılmaz A.E. and İrdemez Ş. (2011), The effect of stirring speed and current density on removal efficiency of poultry slaughterhouse wastewater by electrocoagulation method, Desalination, 280(1), 103-107.

Bo Z., Wen Z., Haejune K., Lu G., Kehan Y. and Chen J. (2012), Onestep fabrication and capacitive behavior of electrochemical double layer capacitor electrodes using vertically-oriented graphene directly grown on metal, Carbon, 50(12), 4379-4387.

Brett, Christopher MA, Brett, AM Oliveira, \& Electrochemistry, Principles. (1993). Methods and Applications: Oxford University Press, Oxford.

Chen G. (2004), Electrochemical technologies in wastewater treatment, Separation and Purification Technology, 38(1), 11-41.

Dalvand A., Gholami M., Joneidi A. and Mahmoodi N.M. (2011), Dye removal, energy consumption and operating cost of electrocoagulation of textile wastewater as a clean process, CLEAN-Soil, Air, Water, 39(7), 665-672.

Djedidi Z., Khaled J.B., Cheikh R.B., Blais J.F., Mercier G. and Tyagi R.D. (2009), Comparative study of dewatering characteristics of metal precipitates generated during treatment of monometallic solutions, Hydrometallurgy, 95(1), 61-69.

El-Ashtoukhy E.S.Z., El-Taweel Y.A., Abdelwahab O. and Nassef E.M. (2013), Treatment of petrochemical wastewater containing phenolic compounds by electrocoagulation using a fixed bed electrochemical reactor, Int. J. Electrochem. Sci, 8, 1534-1550.

EPA. (1996). Best management practices for pollution prevention in the textile industry. In E. P. Agency (Ed.). Ohio, USA.

Hernando J., Lud S.Q., Bruno P., Gruen D.M., Stutzmann M. and Garrido J.A. (2009), Electrochemical impedance spectroscopy of oxidized and hydrogen-terminated nitrogen-induced conductive ultrananocrystalline diamond, Electrochimica Acta, 54(6), 1909-1915.

Holt P., Barton G. and Mitchell C. (1999). Electrocoagulation as a wastewater treatment. The third annual Australian environmental engineering research event, 1000, 41-46.

Martinez-Delgadillo S., Mollinedo-Ponce H., Mendoza-Escamilla V., Gutiérrez-Torres C., Jiménez-Bernal J. and Barrera-Diaz C. (2012), Performance evaluation of an electrochemical reactor used to reduce $\mathrm{Cr}$ (VI) from aqueous media applying CFD simulations, Journal of Cleaner Production, 34, 120-124.

Martinez S.A., Rodriguez M.G. and Barrera C. (2000), A kinetic model that describes removal of chromium $\mathrm{VI}$ from rinsing waters of the metal finishing industry by electrochemical processes, Water Science and Technology, 42(5-6), 55-61.

Merzouk, Belkacem, Madani, Khodir, \& Sekki, Abdelkrim. (2010). Using electrocoagulation-electroflotation technology to treat synthetic solution and textile wastewater, two case studies. Desalination, 250(2), 573-577.

Mollah M.Y.A., Morkovsky P., Gomes J.A.G., Kesmez M., Parga J. and Cocke D.L. (2004), Fundamentals, present and future perspectives of electrocoagulation, Journal of Hazardous Materials, 114(1), 199-210.

Naje A.S., Chelliapan S., Zakaria Z. and Abbas S.A. (2015a), Enhancement of an electrocoagulation process for the treatment of textile wastewater under combined electrical connections using titanium plates, Int. J. Electrochem. Sci, 10, 4495-4512.

Naje A.S., Chelliapan S., Zakaria Z. and Abbas S.A. (2015b), Treatment Performance of Textile Wastewater Using Electrocoagulation (EC) Process under Combined Electrical Connection of Electrodes, International Journal of Electrochemical Science, 10(7), 5924-5941.

Naje A.S., Chelliapan S., Zakaria Z. and Abbas S.A. (2016), Electrocoagulation using a rotated anode: $A$ novel reactor design for textile wastewater treatment, Journal of Environmental Management, 176, 34-44.

Oliveira S, Carlos B. and Oliveira-Brett A.M. (2010), Voltammetric and electrochemical impedance spectroscopy characterization of a cathodic and anodic pre-treated boron doped diamond electrode, Electrochimica Acta, 55(15), 4599-4605.

Sakharova A., Nyikost L. and Pleskov Y. (1992), Adsorption and partial charge transfer at diamond electrodes-I. Phenomenology: an impedance study, Electrochimica Acta, 37(5), 973-978. 
Un U.T. and Aytac E. (2013), Electrocoagulation in a packed bed reactor-complete treatment of color and cod from real textile wastewater, Journal of Environmental Management, 123, 113-119. 